\title{
Public health emergencies: brief history, concepts, and applications
}

\author{
Emergências de saúde pública: breve histórico, conceitos e aplicações
}

Eduardo Hage Carmo

DOI: 10.1590/0103-11042020E2011

\section{Introduction}

Historical change processes in patterns of morbidity and mortality in the world, since the second half of the last century, have been called epidemiological transition. This denomination, established by Omran', aimed at establishing what would be related, in the field of health, to other change processes in population patterns, defined as demographic transition ${ }^{2}$. In summary, the reduction in the fertility rate of the populations, the reduction in infant mortality and the increase in life expectancy at birth, which was observed mainly in developed countries (but which would be followed, after a period of time and uniformly, by less developed countries), would be associated with a reduction in mortality from communicable diseases, with a greater impact on children. This group of diseases was being overcome by chronicdegenerative diseases, more frequent in more advanced age groups. To the three stages of the epidemiological transition process described initially, which would occur according to the development stage of the Country, a fourth stage was added, characterized by the reduction of some chronic diseases, especially cardiovascular diseases ${ }^{3}$. As an explanatory model for these processes, the availability and use of medical technologies (especially antibiotics and vaccines) stood out, which would justify the reduction of communicable diseases, more easily controlled - normally - to these technologies.

However, this conception would not explain the most recent changes observed in less developed countries (especially in Latin America and the Caribbean), as discussed by some authors ${ }^{4}$, who showed different patterns of behavior in the epidemiological trends of these countries. The reduction in communicable diseases in these nations was relative, still coexisting at high levels with the high burden of chronic non-communicable diseases. Based on this evidence, it was considered that these countries would have an incomplete transition process.

Barreto et al. 5 also observed that changes in epidemiological patterns are not linear, that is, they occur differently for each Country and for each population group, depending on the specific living conditions of each of these groups. Using other analyzes of these global changes

1 Fundação Oswaldo Cruz (Fiocruz) - Brasília (DF), Brasil.

ehcarmo@gmail.com as a reference ${ }^{6}$, the authors identified that the determining factors for the improvement of some epidemiological indicators would not be restricted to the use of medical technologies, although these had some influence, but would be related to the improvements in the living conditions of populations. The impact of health technologies (not only medical technologies) 
would also be conditioned by the access of the population not only to these technologies, but also to their own living conditions. Thus, the concept of transition (that is, the transition from a more developed stage to another) would not be sustained, nor would its justification.

This conception is in line with the analysis of changes in the living conditions of the populations addressed from the perspectives of the social determinants of health and social inequalities ${ }^{7}$. According to this perspective, the persistence, or even the deepening of these inequalities, represents a barrier to the improvement of the health conditions of the populations.

Thus, the understanding of changes in epidemiological patterns must dealt with in a more comprehensive way. Beyond the socalled epidemiological transition, the recent scenario is characterized by the occurrence of multiple burden of diseases and conditions (communicable, non-communicable, violence, mental disorders), with the coexistence of several groups of diseases, with greater or lesser expression of each one of these groups, according to the population strata considered ${ }^{8}$.

Regarding communicable diseases, the permanence of factors (among them, the maintenance or deepening of inequalities) that determine or condition the production and spread of these diseases at high levels, changes in the patterns of transmission and circulation of people, goods or merchandise, which favor the increase in the speed of the spread of infectious diseases, provide the conditions for the emergence of epidemics, new diseases, as well as the intensification of old diseases.

Also in the field of non-communicable diseases and conditions, there has been an increase in exposure to risks related to consumption patterns (for example, smoking, unhealthy eating habits, physical inactivity, use of alcohol and drugs, among others), to adverse working conditions, the use of pesticides and other exposures to chemicals and the risks associated with the use of health technologies.
Associated with these factors, the relationship between man and nature - determined by the processes of production, consumption, occupation of space and management of the land, which generate environmental degradation, favoring climate change - has amplified the risk of occurrence of disasters and potentiated its effects on the health of populations, especially the most vulnerable.

\section{Major public health emergencies in the present century}

If we consider the present century as a time limit for a brief analysis, we can identify a series of acute health events, which evidence the high frequency and severity with which they affect the population and the diversity of agents and factors involved in their production and dissemination or spread. For the purpose of this brief description, public health emergencies of different natures and origins, including epidemics, emerging diseases and disasters, are included, not exhaustively.

The year 2001 was marked by the occurrence of two intentional events in the United States, although of quite different nature and characteristics. The first of them, the terrorist attack through the use of civil aviation to the World Trade Center (WTC) and other places in the country that occurred in September of that year, caused the immediate death of approximately 3 thousand people, most of them present at the WTC, as well as 490 thousand people affected by several health problems directly or indirectly related to the event. The attack showed a series of weaknesses in the capacity to respond to events of this nature and magnitude in the Country, but it contributed to the national and global strengthening of these capacities over the years ${ }^{9-11}$.

The Country had not yet recovered from that attack, when, in October of the same year, the intentional spread of Bacillus 
anthracis spores began, using letters, generating 22 cases ( 5 deaths) of Anthrax in several states ${ }^{12}$. This, which was later considered an 'endogenous' bioterrorist act ${ }^{\mathbf{1 3}}$, also caused a collapse in the postal service, health care services and laboratories.

In the following year, an epidemic caused by an unknown disease started in November 2002 in Guangdong province - China, spread to other territories in that country and, later, to other continents, characterizing a pandemic. The disease presented a clinical picture of atypical pneumonia, with a more severe evolution than usually registered for other viral etiologies, being called Severe Acute Respiratory Syndrome (Sars). With a new coronavirus $^{\mathbf{1 4}}$ as etiologic agent, it produced 8,098 cases (774 deaths) in 26 countries. From some episodes of transmission that occurred at the Metropole hotel in Hong Kong, in February $2003^{15}$, there was international dissemination to other continents through air travel, showing how a pandemic could be produced in a period of little more than 24 hours. Another important feature of this pandemic was the amplification of transmission in the hospital environment (and other health services), which made health professionals targets of the disease and potential transmitters to other locations.

In 2004, the occurrence of cases of human influenza by the $\mathrm{H} 5 \mathrm{~N} 1$ virus in Vietnam and Thailand triggered the alert for the possibility of the occurrence of a pandemic due to this virus, considering that the entire world population would be susceptible to infection. These cases were associated with an epidemic that occurred in birds in late 2003, in eight countries in Asia, which indicated inter-species transmission, although this transmission had been detected since 1997 in Hong Kong ${ }^{16}$. As it is a new strain of influenza viruses infecting humans, the possibility of sustained inter-human transmission, the reduced efficacy of the antivirals used and the severity of the cases previously known (lethality around 50\%) produced a series of possible parallels with pandemics previously caused by influenza viruses, with their respective death estimates: H1N1 in 1918 (more than 40 million), H2N2 in 1957 (4 million) and H3N2 in 1968 (1 million).

In 2005, an event of a non-infectious nature that occurred in the United States caused immense damage to the population, in addition to material and economic losses (estimated cost of US\$ 108 billion) and displacement of the population. Hurricane Katrina that hit New Orleans that year had devastating effects, killing more than 1,500 people, in addition to the missing. Despite the lessons learned from previous events, especially with the 2001 terrorist attack, facing the consequences of this disaster was considered very insufficient by the National Congress itself ${ }^{17}$.

The H5N1 influenza pandemic, expected in previous years, did not materialize, but, from February 2009 on, a new pandemic began, this time, produced by the influenza A [H1Nl] pdm09 virus. This pandemic was considered the first public health emergency of international importance, already adopting the new criteria of the International Health Regulations (IHR 2005), which had come into force two years earlier ${ }^{\mathbf{1 8}}$. The pandemic started in February of that year, on the border of Mexico with the United States, and the initial estimates indicated a high severity, which were based on a study carried out in Mexico, which showed a $41 \%$ lethality during the beginning of the pandemic ${ }^{19}$. However, these estimates were not confirmed, and the subsequent projections for the number of deaths were between 123,000 and 395,600 deaths ${ }^{\mathbf{1 8}}$. It is not possible to estimate, with good accuracy, the lethality for this pandemic, given that the number of cases was suspended globally, already in 2009.

Brazil was also seriously affected by the pandemic, with rapid dissemination within a few weeks of its onset. By the end of 2009 , 50,482 serious cases and 2,060 deaths had been confirmed, especially in the southern 
region of the Country. As Brazil implemented a system for the detection of serious cases, it was possible to estimate lethality (4.1\%), which was within the average observed for seasonal influenza ${ }^{20,21}$.

In March 2011, after being hit by a tsunami caused by a seaquake, the Fukushima Nuclear Power Plant reported the melting of three turbines, releasing significant amounts of radioactive material, which was the largest nuclear disaster since the Chernobyl nuclear accident in $1986^{22}$. The number of people affected, or who may still manifest diseases related to the accident, is unclear, but it is estimated that 18,500 people died, with 200 thousand being affected by the event ${ }^{11}$.

Between the end of 2013 and the beginning of 2014, an epidemic by the Ebola virus began to affect the Republic of Guinea, rapidly expanding to Liberia and Sierra Leone (West Africa) and producing a total of 28,616 cases with 11,310 deaths ${ }^{23,24}$, which would correspond to a lethality of $39.5 \%$. However, this percentage was probably underestimated, considering the average lethality recorded in previous epidemics and the precariousness of health services in the countries involved ${ }^{25}$. This epidemic was also considered by the World Health Organization (WHO) to be a public health emergency of international concern, according to the criteria of the IHR 2005, and lasted two years, ending on March 29, 2016²4.

In the same period, two epidemics were spreading in the American continent, both transmitted by the same vector, Aedes aegypti: Chikungunya fever and Zika virus infection, with theirs serious consequences. These epidemics have seriously affected Brazil since 2014, especially after detecting the increase in neurological syndromes (in the case of Chikungunya and Zika) and the congenital adverse effects associated with maternal infection by the Zika virus in late $2015^{\mathbf{2 6}, 27}$. With the new findings referring to congenital manifestations by the Zika virus in Brazil and with the spread to other countries, four months after the emergency declaration in the country, WHO declared a public health emergency of international concern ${ }^{\mathbf{2 8}}$.

Although epidemics of the Zika virus have already been reported in Africa and Asia, until then these serious manifestations of congenital infection were unknown. However, after its occurrence in northeastern Brazil, the broad spectrum of manifestations came to be known, which were found not only in the country, but in all other continents, although to a lesser extent. Since the beginning of the epidemic until May 2019, more than 3,406 cases of what came to be later called Congenital Zika Syndrome have been confirmed ${ }^{29}$. In many countries where the epidemic has spread, the magnitude of the syndrome is not precisely known, although infection by the Zika virus has already spread to 87 countries by July $2019^{30}$.

Still in Brazil, in 2017, at the same time that there was a significant reduction in the epidemic by the Zika virus, a new epidemic of Wild Yellow Fever began. The country had already faced epidemics in the previous two decades, to a lesser extent, for example, in 1999/2000 (76 and 85 cases respectively) and 2008/2009 (46 and 47 cases respectively) ${ }^{31}$. In the epidemic that began in the monitoring period (current form of temporal analysis of cases by the Ministry of Health) of 2016/2017, 768 human cases were confirmed, with a great expansion of the transmission area of this virus in the east and south of the Country ${ }^{29}$. In the subsequent periods, there was continuity in the geographic expansion of the epidemic, with a record of $1,376(2017 / 2018)$ and 88 confirmed cases (2018/2019). In all these last periods, as it had been registered since the end of the last century, cases were recorded in areas where there was no record for more than 40 years, indicating a change in the geographical pattern of the disease in Brazil ${ }^{31}$.

As of mid-2018, the African continent was again affected by an epidemic by the Ebola virus, this time in the Democratic Republic of Congo. This country had already periodically presented epidemics in smaller proportions, 
the last ones being in 2014 and 2017, due to the situation of vulnerability (wars, poverty and extreme hunger). However, the current epidemic has assumed a more relevant magnitude than the previous ones, with a record of 3,175 cases, among which, 2,122 evolved to death (lethality 67\%) by September 24, $2019^{32}$.

In Brazil, a recent epidemic has been caused by measles. Although, in recent years, there have been records of epidemics located in some states (Pernambuco in 2013/2014 and Ceará in $2014 / 2015)^{33}$, as of 2018, the spread and magnitude of this event assumed much greater proportions, leading to loss of the disease elimination certificate granted by Pan American Health Organization (Paho) in 2016. With the epidemic in the northern region of the Country in 2018, linked to the epidemic in Venezuela - between January and September 2019 in all regions, but predominating in São Paulo (95\% of the cases) ${ }^{33}$-, it became evident that the reintroduction of the disease in Brazil found a favorable environment due, among other factors, to low coverage in some population groups, as well as the continuous import of cases from countries that never achieved elimination, especially in Europe and Asia. It is also worth remembering that the reintroduction of the disease in the Americas did not occur only in Brazil and Venezuela, but also affected other countries in the region such as the United States, which also faced an important epidemic (31 states affected) ${ }^{33}$.

Still in that year, the Country was the stage of another tragedy, considered one of the biggest environmental disasters, due to the rupture of the mining tailings dam of the company Vale S.A. in Brumadinho (MG). Approximately 300 people have died or are missing (bodies are still being found), 18 municipalities and 2 river basins have been directly affected and environmental damage is still being measured. This was the second event related to the tailings dam in recent years, considering that, in 2015, a disaster with similar characteristics occurred in Mariana (MG), also affecting the state of Espírito Santo, involving the company
Samarco (subsidiary of Vale SA), resulting in the death of 19 people, in addition to environmental damage ${ }^{35}$.

These health events are increasingly expressed in an abrupt, unusual way, presenting a high impact on the population and exceeding the response capacity of health services. In order to characterize the way in which these events occur and to identify the most appropriate measures for detection and response, some terms have been used in international literature and by health services, which will be discussed below.

\section{On the definitions of emerging and re-emerging diseases}

The emergence of new diseases due to the occurrence of new etiological agents, strains or mechanisms of transmission, changes in existing agents (with an increase in virulence or pathogenicity) and the introduction of agents in new areas hitherto considered to be indemnities, which are potentially generating factors epidemics, in addition to the development of new techniques that allow the detection of these new diseases, stimulated the development of concepts that sought to characterize these processes and contribute to their detection, prevention and control. Likewise, the resurgence of diseases previously considered to be controlled would also represent a risk of producing epidemics, given that the population of a given territory could be susceptible, depending on the period in which the agent was not circulating or with little circulation in that space ${ }^{36}$.

For the first set of events, the term emergent diseases was used, while for the second, the term re-emerging diseases. These terms emerged in the early 1990s, initially used by the Institute of Medicine ${ }^{37}$ and later by the Centers for Disease Control and Prevention (CDC) of the United States, defined emerging infectious 
diseases as "diseases of infectious origin whose incidence in humans has increased within the past two decades or threatens to increase in the near future"38(2).

Barreto et al. ${ }^{39}$ identified some inaccuracies in the concept of emerging diseases, although it is widely used in the world literature and adopted by several health organizations: a) it establishes an artificial period (two decades) to characterize an infection as emerging; $b$ ) it does not establish a territorial dimension so that the analysis of the distribution of a disease is properly contextualized; c) it does not establish parameters to characterize an increase in the incidence of a disease, that is, it does not consider the magnitude of that increase and the previous historical trend.

In 2003, the Institute of Medicine updated the 1992 document, defining an emerging infectious disease as

[...] a newly recognized, clinically distinct infectious disease or a known infectious disease whose reported incidence is increasing in a given place or among a specific population ${ }^{40(32)}$.

This new definition is more precise, as it incorporates the spatial dimension (that is, it requires territorial contextualization) and does not establish an artificial period, but, as Barreto et al. ${ }^{39}$ referred, there was still an imprecision on the parameters to characterize an increase in the incidence of a disease.

As Carmo et al. ${ }^{36}$ pointed out, for a better characterization of an infectious disease as emerging, it is necessary to analyze the occurrence in a contextualized way for each population, territory and historical time, in which the diseases affect. It should be analyzed whether its appearance or the increase in its incidence has epidemiological relevance for a defined population and territory. Regarding the time to be considered in the characterization of a disease as emerging or re-emerging, Waldman ${ }^{41}$ recalls that they highlight the need for the definition of the behavior's cutting (temporal) of a disease to take into account its historical pattern of evolution. We can say that it would not be possible to establish a single period, for all diseases, for the characterization of an emergency or re-emergence. This choice will always be arbitrary and adopted to facilitate the description of a set of diseases.

\section{Definitions of public health emergencies}

With the approval of the new IHR by the World Health Assembly in 2005, another concept was disseminated, that of public health emergency ${ }^{\mathbf{4 2}}$.

However, this concept was not initially established by IHR 2005, but it was already present in a series of publications, although almost always related to the application of interventions by national organizations to control events that could generate epidemics or before epidemics already installed. The term public health emergency was already included in a regulatory act of the United States government in $1984^{43}$. Whether in regulatory acts or in some publications, this term is generally used to define the status of a health problem that requires health authorities to adopt immediate measures for its control, in particular measures restricting individual rights (for example, quarantine, isolation, compulsory examination) or that justify the mobilization of resources (human, infrastructure, financial). The use of the term public health emergency in these documents does not provide a definition, in which the criteria by which a health event can be classified as such are established ${ }^{\mathbf{4 4}}$.

Initially, the use of the term in that country applied predominantly to communicable diseases. However, with the intentional use of biological weapons (release of the Anthrax bacillus in 2001), with the terrorist attack of September 2001 and with the occurrence of major disasters such as Hurricane Katrina, the term started to be applied every more to 
characterize events of a different nature ${ }^{45,46}$. Even so, there was a great diversity in its use in legal instruments for the definition of the term emergency between the states of that country ${ }^{45}$.

The term public health emergency represents a central element in IHR 2005, but it must be interpreted as to its application for the purposes of this instrument. The IHR 2005 aims to establish measures to expand national capacities to detect and respond to the risks of the spread or propagation (in the case of non-infectious events) of diseases between countries. In this instrument, the term used is a public health emergency of international concern - defined by:

An extraordinary event which is determined to constitute a public health risk to other States through the international spread of disease [and] to potentially require a coordinated international response $\mathbf{4 2 ( 9 )}^{\mathbf{4}}$

Still, according to the definitions of the IHR 2005, "Event is the manifestation of disease or an occurrence that creates a potential for disease"

Events that may constitute emergencies, therefore, are not restricted to infectious diseases (may include events of a chemical, radionuclear nature or disasters) nor are they limited to the occurrence of damage to the health of the population (case or death due to a certain disease), but include risk factors for its occurrence.

For the analysis of events that may constitute a public health emergency of international concern, some criteria are evaluated in a contextualized way for a specific population, time and space, in addition to considering aspects related to the likelihood of international restrictions on the transit of people, goods and merchandise and international trade. For this purpose, an instrument that has instructions for its application and includes an algorithm was developed, with some questions that support the interpretation of the events under analysis ${ }^{47}$.
As pointed out by Carmo et al. ${ }^{36}$, the use and adaptation of the concept of public health emergency made more precise and applicable by the national epidemiological surveillance systems the definition of events that should be monitored, proposing and implementing actions aimed at preventing or decreasing the likelihood of the spread or propagation of diseases. Furthermore, when dealing with risks, it allows the adoption of anticipatory measures, with the potential to prevent or reduce the occurrence of damage to the population's health.

With these characteristics, the definition used for the concept of public health emergency is more precise than for the term emerging diseases and broader than the concept of epidemic, as both are restricted to the occurrence of damage, in addition to first concept applies exclusively to infectious diseases. It is worth noting that some emerging diseases and epidemics, whenever they represent a risk of spread (national or international), can constitute a public health emergency ${ }^{36}$.

The public health emergency concept has been used routinely by countries that adopted the IHR 2005, through the active monitoring of public health events (with the use of active surveillance tools and electronic capture of rumors); and its wide use has allowed an increase in the detection of potential emergencies since the implementation of the Regulation.

In Brazil, this concept was adapted to detect, analyze and respond to potential emergencies of national importance, that is, which present a risk of dissemination or propagation in the national territory. In 2011, Presidential Decree $\mathrm{n}^{0}$ 7,616 was published, through which three situations were defined that could characterize a public health emergency: a) epidemiological (outbreaks and epidemics); b) disasters; c) lack of assistance ${ }^{\mathbf{4 8}}$. It is evident that, except in the event of disasters, the definition of a public health emergency would apply only when damage to health occurred, that is, other risk situations would not be considered emergencies. 


\section{Conclusions}

As seen before, the term public health emergency, in the national and international context, has been used to describe situations (called public health events) that constitute or present an immediate risk of production, dissemination or aggravation of damage to the health of the population, regardless nature or origin. This term, when applied, has always involved the need to adopt immediate public health measures, involving not only medical attention and health surveillance, but also other areas according to the characteristics of the event. That is, it is a concept aimed at public health practice.

For this purpose, it requires from the health authorities and from all the other actors involved in the response an assessment of the context and characteristics of each event, which is not an easy task, as this information is often known in the course of the emergency itself.

Some processes, mechanisms and instruments can be further strengthened to improve this response capacity, which are related to the definition of the emergency concept itself. As an example, considering that it will be the subject of other publications in this Journal: a) development of methodologies for grading events that may constitute public health emergencies, including the characterization of warning signs and pre-emergency stages; b) preparation of preparedness and response plans that include the adoption of criteria for the classification of public health emergencies; c) carrying out exercises to evaluate the application of these instruments.

This is an urgent task to be carried out by the health authorities, the scientific community and other actors involved with the theme, due to the fact that the conditions for the intensification of public health emergencies have been increasing more and more. Climate change has already created conditions for many events of great magnitude to occur more frequently, in a short period of time, and to cause greater damage to populations ${ }^{49}$. The prospects for this process to intensify with the increase in temperature above $1.5^{\circ} \mathrm{C}$ to $2^{\circ} \mathrm{C}$ in the coming decades are already given, and some scenarios are already described ${ }^{50}$. Although these scenarios still present some degree of uncertainty, it is certain that the impact on the health of populations, especially the most vulnerable, of the production of public health emergencies will be incalculable. In view of this scenario, it is our duty, now, to contribute so that its effects are as small as possible.

\section{Collaborator}

Carmo EH (0000-0001-6343-9967)* is responsible for elaborating the manuscript. 


\section{References}

1. Omram AR. The epidemiological transition: a theory of the epidemiology of population change. MilbankQ. 1971; 49(4):509-583.

2. Frederiksen H. Feedbacks in economic and demographic transition. Science. 1969; 166(3907):837-47.

3. Olshansky SJ, Ault BA. The fourth stage of the epidemiologic transition. The age of delayed degenerative diseases. MilbankQ. 1986; 64(3):355-391.

4. Frenk J, Frejka T, Bobadilla JL, et al. La transition epidemiológica en América Latina. Boletin OSP. 1991; 111(6):485-496.

5. Barreto ML, Carmo EH, Noronha CV, et al. Mudanças dos padrões de morbi-mortalidade: uma revisão crítica das abordagens epidemiológicas. Physis. 1993; 3(1):127-146.

6. McKeown T. The role of medicine: dream, mirage or nemesis? Oxford: Basil Blakwell; 1979.

7. Buss PM, Pellegrini Filho A. A saúde e seus determinantes sociais. Physis. 2007; 17(1):77-93.

8. Teixeira MG, Paixão ES, Costa MCN. Cambios epidemiológicos recientes en América del Sur. In: Carmo EH, Gemal A, Oliveira S, organizadores. Vigilancia en Salud en Suramérica: epidemiológica, sanitaria y ambiental. Rio de Janeiro: ISAGS; 2013. p. 41-55.

9. Feenney JM, Wallack MK. Taking the terror out of terrorism: mortality data after 9/11. Lancet. 2011; 378(9794):851-952.

10. Khan AS. Public health preparedness and response in the USA since 9/11: a national health security imperative. Lancet. 2011; 378(9794):953-56.

11. Lucchini RG, Hashim D, Acquilla S, et al. A comparative assessment of major international disasters: the need for exposure assessment, systematic emergency preparedness, and lifetime health care. BMC
Public Health [internet]. 2017 [acesso em 2019 jan 25]; 17(1):46. Disponível em: https://bmcpublichealth.biomedcentral.com/articles/10.1186/s12889-0163939-3.

12. Jernigan DB, Raghunathan PL, Bell BP, et al. Investigation of Bioterrorism Related Anthrax, United States, 2001: Epidemiologic Findings. Emerg. Infect. Diseases. 2002; 8(10):1019-1028.

13. Guillemin J. American Anthrax: Fear, Crime, and the Investigation of the Nation's Deadliest Bioterror Attack. New York: Times book; 2011.

14. Drosten C, Günther S, Preiser W, et al. Identification of a Novel Coronavirus in Patients with Severe Acute Respiratory Syndrome. N Engl J Med. 2003; 348(20):1967-76.

15. Hung LS. The SARS epidemic in Hong Kong: what lessons have we learned? J R Soc Med. 2003; 96(8):374378.

16. Peiris JSM, Jong MD, Guanet Y. Avian Influenza Virus (H5N1): a Threat to Human Health. Clin Microbiol Rev. 2007; 20(2):243-267.

17. U.S. Government Printing Office. Hurricane Katrina: A Nation still unprepared. Special report of the Committee on homeland security and governmental affair. Washington, DF: U.S. Government Printing Office; 2006. [acesso em 2019 set 28]. Disponível em: https://www.congress.gov/109/crpt/srpt322/CRPT-109srpt322.pdf.

18. Fineberg HV. Pandemic Preparedness and Response - Lessons from the H1N1 Influenza of 2009. N Engl J Med. 2014; (370):1335-42.

19. Domínguez-Cherit G, Lapinsky SE, Macias AE, et al. Critically Ill Patients With 2009 Influenza A(H1N1) in Mexico. JAMA. 2009; (302):1880-7.

20. Oliveira WK, Carmo EH, Penna GO, et al. Pandemic 
H1N1 influenza in Brazil: Analysis of the first 34,506 notified cases of influenza- like illness with severe acute respiratory infection (SARI). Euro Surveill. 2009; 14(43):pii19362.

21. Brasil. Ministério da Saúde. Informe técnico de Influenza [internet]. 2012. [acesso em 2019 set 28]. Disponível em: http://portalsaude.saude.gov.br/images/ pdf/2014/maio/22/informe- influenza- 2009-20102011- 220514.pdf.

22. Hippel FN. The radiological and psychological consequences of the Fukushima Daiichi accident. Bullet. Atomic Scient. 2011; 67(5):27-36.

23. World Health Organization. Origins of the 2014 Ebola epidemic. One year into the Ebola epidemic [internet]. 2015. [acesso em 2019 set 28]. Disponível em: https://www.who.int/csr/disease/ebola/one-year-report/virus-origin/en/.

24. World Health Organization. Situation report. Ebola virus disease [internet]. 2016. [acesso em 2019 set 28]. Disponível em: http://apps.who.int/iris/bitstream/10665/208883/1/ebolasitrep_10Jun2016_eng. pdf?ua=1.

25. Cenciarelli O, Pietropaoli S, Malizia A, et al. Ebola Virus Disease 2013-2014 Outbreak in West Africa: An Analysis of the Epidemic Spread and Response. Inter. J. Microbiol [internet]. 2015 [acesso em 2019 set 28]; (2015):1-12. Disponível em: https://doi. org/10.1155/2015/769121.

26. Brito CAA, Teixeira MG. Increased number of deaths during a chikungunya epidemic in Pernambuco, Brazil. Mem. Inst. Oswaldo Cruz. 2017; 112(9):650-651.

27. Oliveira WK, França GVA, Carmo EH, et al. Infection- related microcephaly after the 2015 and 2016 Zika virus outbreaks in Brazil: a surveillance- based analysis. Lancet. 2017; 390(10097):861-870.

28. World Health Organization. Emergencies: the history of Zika virus, 2016 [internet]. [acesso em 2019 set 28]. Disponível em: https://www.who.int/emergencies/zika-virus/timeline/en/.
29. Brasil. Ministério da Saúde. Vigilância em saúde no Brasil 2003|2019: da criação da Secretaria de Vigilância em Saúde aos dias atuais. Bol Epidemiol [internet]. 2019 [acesso em 2019 set 28]; 50(esp):1-154. Disponível em: http://www.rets.epsjv.fiocruz.br/biblioteca/vigilancia-em-saude-no-brasil-20032019-da-criacao-da-secretaria-de-vigilancia-em-saude.

30. World Health Organization. Zika epidemiology update [internet]. 2019. [acesso em 2019 set 28]. Disponível em: https://www.who.int/emergencies/diseases/ zika/epidemiology-update/en/.

31. Teixeira MG, Costa MCN, Paixão ES, et al. Conquistas do SUS no enfrentamento das doenças transmissíveis. Ciênc. Saúde Colet. 2018; 23(6):1819-1828.

32. World Health Organization. Ebola virus disease Democratic Republic of the Congo. Disease outbreak news: Update [internet]. 2019 [acesso em 2019 set 28]. Disponível em: https://www.who.int/csr/don/14-november-2019-ebola-drc/en/.

33. Brasil. Ministério da Saúde. Secretaria de Vigilância em Saúde. Boletim Epidemiológico [internet]. 2019. [acesso em 2019 set 28]. Disponível em: https://portalarquivos2.saude.gov.br/images/pdf/2019/setembro/25/boletim-especial-21agol9-web.pdf?fbclid= IwAR3qTQYyo5tG7dYLNXWfj4ymtmIAoJtlolbTn wToAPConwrDnoVpvokyzvo.

34. Centers for Disease Control and Prevention. Measles Cases and Outbreaks [internet]. 2019. [acesso em 2019 set 28]. Disponível em: https://www.cdc.gov/ measles/cases- outbreaks.html.

35. Freitas CM, Barcellos C, Fróes ACIR, et al. Da Samarco em Mariana à Vale em Brumadinho: desastres em barragens de mineração e Saúde Coletiva. Cad. Saúde Pública. 2019; 35(5):1-7.

36. Carmo EH, Oliveira WK, Penna G. Emergências de saúde pública: conceito, caracterização, preparação e resposta. Est. avançados. 2008; 22(64):19-31.

37. Institute of Medicine. Emerging infections: microbial threats to health in the United States. Washing- 
ton, DC: National Academy Press; 1992.

38. Centers for Disease Control and Prevention. Addressing emerging infectious disease threats: a prevention strategy for the United States. Georgia: US Department of Health and Human Services; Public Health Services; 1994.

39. Barreto ML, Teixeira MG, Carmo EH. Infectious diseases epidemiology. J. Epidemiol. Community Health 2006; 60:192-195

40. Institute of Medicine. Microbial threats to health: emergency, detection and response. Washington, DC: National Academy Press; 2003.

41. Waldman EA. Doenças infecciosas emergentes e reemergentes. Revista USP. 2001; (51):128-137.

42. World Health Organization. International Health Regulations (2005). 3. ed. Geneva: WHO; 2016.

43. United States. United States Code. 1982. Titles 4250. Washington, DC: Government Printing Office; 1984. [Supplement I]. [acesso em 2019 set 29]. Disponível em: https://books.google.com.br/boo $\mathrm{ks}$ ? id=fGWbAAAAMAAJ\&pg=PA5\&lpg=PA5\&d q=July+1,+1944,+ch.+373,+title+III,+\%C2\%A7\%E $2 \% 80 \%$ AF $319 \&$ source=bl\&ots=SKT6_Za6hb\&si $\mathrm{g}=\mathrm{ACfU} 3 \mathrm{U} 3 \mathrm{wnhVaSysZpPqxRRkpqCEAIQJsw}$ Q\&hl=pt- BR\&sa=X\&ved=2ahUKEwj8sfHwhO_ kAhVxG7kGHePEB1EQ6AEwAHoECAgQAQ\# $\mathrm{v}=$ onepage $\& \mathrm{q}=\mathrm{July} \% 201 \% 2 \mathrm{C} \% 201944 \% 2 \mathrm{C} \% 20$ ch. \%20373\%2 C \% 20title\%2 OIII\%2 C \% 20 $\% \mathrm{C} 2 \% \mathrm{~A} 7 \% \mathrm{E} 2 \% 80 \% \mathrm{AF} 319 \& \mathrm{f}=$ false.

44. Haffajee R, Parmet WE, Mello MM, et al. What Is a Public Health "Emergency”? N Engl J Med. 2014; (371):986-988

45. Salinsky E. Public Health Emergency Preparedness: Fundamentals of the "System" [internet]. 2002. [aces- so em 2019 set 29]. Disponível em: https://www.semanticscholar.org/paper/Public- Health- Emergency- Preparedness\%3A- Fundamentals- Salinsky/ a0ac99f3530b6a8fe43546b267b7d1dbe130400c.

46. Center for Law and Public Health's; Georgetown and Johns Hopkins Universities. The Model State Emergency Health Powers Act: as of October 23, 2001 [internet]. Atlanta: Centers for Disease Control and Prevention; 2001. [acesso em 2019 set 29]. Disponível em: https://biotech.law.lsu.edu/blaw/bt/MSEHPA.pdf.

47. World Health Organization. WHO guidance for the use of Annex 2 of the International Health Regulations (2005) [internet]. 2010. [acesso em 2019 set 28]. Disponível em: https://www.who.int/ihr/publications/annex_2_guidance/en/.

48. Brasil. Decreto $\mathrm{n}^{0} 7.616$, de 17 de Novembro de 2011 [internet]. Dispõe sobre a declaração de Emergência em Saúde Pública de Importância Nacional - ESPIN e institui a Força Nacional do Sistema Único de Saúde - FN- SUS. Diário Oficial da União. 18 Nov 2011. [acesso em 2019 set 29]. Disponível em: http://www. planalto.gov.br/ccivil_03/_Ato2011- 2014/2011/Decreto/D7616.htm.

49. Solomon CG, La Rocque RC. Climate Change - A Health Emergency. N Engl J Med. 2019; (380):209211.

50. Intergovernmental Panel on Climate Change. Especial report. Global Warming of $1.5^{\circ} \mathrm{C}$ [internet]. 2018. [acesso em 2019 set 28]. Disponível em: https://www. ipcc.ch/sr15/.

Received on 09/29/2019

Approved on 05/06/2020

Conflict of interests: non-existent

Financial support: non-existent 